ELK ASIA PACIFIC JOURNAL OF MECHANICAL ENGINEERING RESEARCH

ISSN 2349-9368 (Online); EAPJMER/issn. 2349-9368/2016; Volume 4 Issue 2 (2018)

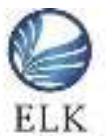

Asia Pacific Journals

www.elkjournals.com

\title{
GREEN FLUSHING: A SOLAR POWERED TOILET FLUSH SYSTEM WITH INBUILT WASTEWATER TREATMENT, RAINWATER HARVESTING AND BIOFUEL PRODUCTION SYSTEM
}

\begin{tabular}{|c|c|c|}
\hline $\begin{array}{c}\text { RAJAT .S. RATHOUR } \\
\text { Mechanical \& Automation } \\
\text { Engineering, Amity School } \\
\text { of Engineering \& } \\
\text { Technology, Amity School } \\
\text { of Engineering \& } \\
\text { Technology, Amity } \\
\text { University Uttar Pradesh. } \\
\text { rajatrathour1995@ outlook.c } \\
\underline{\text { om }}\end{array}$ & $\begin{array}{c}\text { NIKHITA WADHAWAN } \\
\text { Mechanical \& Automation } \\
\text { Engineering, Amity School } \\
\text { of Engineering \& } \\
\text { Technology, Amity School } \\
\text { of Engineering \& } \\
\text { Technology, Amity } \\
\text { University Uttar Pradesh. } \\
\underline{\text { nikhitawadhawan@ gmail.c }} \\
\underline{\text { om }}\end{array}$ & $\begin{array}{c}\text { KARTIK AGARWAL } \\
\text { Mechanical \& Automation } \\
\text { Engineering, Amity School } \\
\text { of Engineering \& } \\
\text { Technology, Amity School } \\
\text { of Engineering \& } \\
\text { Technology, Amity } \\
\text { University Uttar Pradesh. } \\
\frac{\text { Kartik.agarwal73@ gmail.c }}{\text { om }}\end{array}$ \\
\hline
\end{tabular}

\begin{abstract}
This novel research work proposes a sustainable green flushing system wherein the benefits of waste water treatment and recycling of rainwater have been combined with a novel solar powered flush system for general household and commercial utilities. With inbuilt biogas \& natural fertiliser production system that repurposes human waste into a reusable product, this avant-garde technique serves as an economical and efficient tactic to prevent water and electrical wastage. By recycling the used water containing impurities, after it has been commissioned once, conserves potable water and additional energy expended in pumping underground natural bore well water with boring submersibles followed by purification and filtration by governmental bodies, for the second time. Furthermore, harvesting of rainwater provides an additional source of water intake for flushing purpose. The recycled wastewater along with the harvested rainwater will gradually be stored in a tandem district regulating module, which will be regularly treated with a mixture of chlorine \& water disinfectant solution in order to provide reassurance regarding sanitation and prevention of bacterial or algae growth. The tandem district regulating module storing the recycled wastewater will be connected to the inlet of toilet's flush. This method of green flushing toilet system will save approximately 360 million litres of fresh potable government supply water or groundwater per annum and approximately 20,000 units of electricity per month for an average colony or medium scale industry. In addition to that this system will be able to produce natural fertilizers to be used for farming purposes, thereby gradually reducing pollution of lakes, canals and rivers due to human excretion across the country and consequently assisting organic crop fertilisation.
\end{abstract}

Keywords: wastewater recycling; energy conservation; toilet flush system; solar power; agrobiotechnology; pollution 


\section{INTRODUCTION}

The natural abundance of water across the globe is uneven and most of it is inaccessible. As a matter of fact, there is only $3 \%$ fresh water available for global consumption and of this limited capacity, $69 \%$ is constituted by glaciers, $30 \%$ in stored underground reserves and about less than $1 \%$ is available in lakes, rivers \& swamps. The remaining $97 \%$ of total water available is constituted in sea across the globe which is deemed unfit for consumption and requires exorbitant treatment costs to be converted into a potable form at an industrial scale. [1]

Gradually with advancements in science, engineering \& technology we have reached version 4.0 in Industrial Revolution as of 2018. No matter how green the manufacturing system is, pollutants are generated as by-products [2]. Presently, developing countries and developed countries discharge more than $80 \%$ of sewage directly into natural water resources without any treatment causing widespread damage to inland water bodies and coastal shores [2]. Most impurities in contaminated water are microbial pathogens, oxygen consuming materials, suspended human excreta or phosphorous and nitrogen components whose presence renders the natural resource as a possible disease causing threat [2].

Water plays a prominent role in human life on a day to day basis. With ever growing population, there is a growing demand for pure water and very less of it is available in today's date hence its scarcity is creating a pressing need for technical innovations for safer storage and purification processes. Harvesting rain water is one resolution to water scarcity but increased emphasis is required for economical recycling of grey and black water.

\section{PEER RESEARCH WORK}

As per our research on recycling grey \& black water, various methods and innovations have been worked out and published. Of the few published works in the specific area of economical flushing, emphasis is laid on use of pressure sensor in order to calculate the amount of water to be discharged for the process of flushing. A control device which is assembled with toilet seat, constituting a pre-installed pressure 
sensor beneath it, automatically calculates and distinguishes between urine \& stool in real time, to discharge the net amount of water for the same purpose. In this mechanism the flag bit of pressure sensor is connected to the input chip assembled with frame casing of commode, which automatically now can distinguish between urine and stool based on duration of human pressure on toilet seat [3].

A second research paper which also focuses on economical toilet flushing system uses dichotomous flush channels which help in drawing out a pattern flush system. Having manual switches to trigger and alternate between stool flushing and urine flushing. A debilitating measured unit of water is used for the purpose of individual flushing. Also the toilet stool flushing mechanism is assembled with human body interaction system, one that is based on the duration of human interaction and real time calculation enabling the decision of the quantity of water to be used for flushing, which gradually helps in simplifying the apparatus and automating the operational cycle [4].
Now focusing on third area of research in the same field of economic flushing comprises use of infra-red technology with real time monitoring which provides signals to control the flush tank which in turn provides us with water saving. This device is assembled with infrared sensing module with an automation valve control mechanism. In this case, the input of the microcontroller $\mathrm{I} / \mathrm{O}$ is connected in line with infrared transmitter and receiver connected to output of microcontroller I/O. A control pulse motor mechanism is in series with the main hose of water supply line in order to automate automatic closing and opening of the valve with the help of dual switch. The switch mechanism comprises of two set actuators which are yet again connected to the output ends of the coil of the pulse motor [5].

A fourth publication in the domain of green economical flushing discusses water economisation mechanism for a flush valve type toilet bowl to reduce and regulate the flushing process mainly by controlling the flow of water for the specific purpose of urine or faeces. This water saving device mechanism with automated flush valve type toilet bowl 
is assembled with a housing having an internal cavity. This housing is attached with a sensor controller attached on the upper side of housing to sense a user interface and automatically identify urine or faeces and drain the same with washing water [6].

Of the other research works, a previous innovation relates to a system for the treatment of aircraft grey and black water on board in order to discharge the same into atmosphere during the flight, utilising the differential pressure between outside atmosphere and cabin pressure of aeroplane. This system is assembled with a filter bed to remove the suspended solid waste out of black water and also to eliminate other impurities and contamination from black and grey water, which may further also include a mechanism to purify the segregated water to potable water standards and can further be recirculated after treatment on aircraft for various uses [7].

As with the review of prior scholarly research discussed above, it can be clearly noted that till date various mechanism, systems and innovations have come up for clean economical flushing mechanism that usually recycles the grey water collected from household activities and then is used for flushing mechanism. Generally these systems comprise of two flushing mechanisms for stool and urine specifically and the conclusive judgement after studying various articles, it is noted that the quantity of water which is flushed is directly related to time duration of human interaction with mechanism, but as a matter of fact, longer duration of interaction doesn't necessitate stool movement and gradually it corresponds to drainage of fresh water plus recycled water, which eventually is a loss.

Hence after considering a number of prior studies it is noted that there is a need of improvisation in previous methods and systems to save natural and clean water from being drained in to sewage and simultaneous protection of the same from pollution.

Therefore this work majorly focuses on recycling of both grey and black water completely by use of basic engineering fundamentals. The sources of such water, mainly showers, sinks, kitchen, laundry waste and air conditioners units will be converted into sources of reusable water, fit for flushing. 
ELK ASIA PACIFIC JOURNAL OF MECHANICAL ENGINEERING RESEARCH

ISSN 2349-9368 (Online); EAPJMER/issn. 2349-9368/2016; Volume 4 Issue 2 (2018)

\section{METHODOLOGY}

\subsection{Proposed System Design and Mechanism}

Collection of black water from across the toilets and lavatories across the household through a common sewage line and collection of grey water from kitchen sinks, washing machine outlets, outdoor air conditioning units and other sources of grey water generation. The collection from sewage line is then allowed to settle in a district regulating system (Double Stream) enclosed with air tight vapour permeation membrane module. The outward flow of black water is then segmented through bottom of district regulating system, in order to leave only suspended stool waste into the gasket module. Post this step, the output black water is passed through a single membrane filter and collected in a storage tank.

Similarly, the collection of grey water from drainage line is allowed to pass through a single membrane filter in order to remove minor impurities and the same grey water post filtration from single membrane filter is collected into a storage tank.
Then mixture of both black and grey water post filtration is allowed to settle in tank in order to make sure if any impurities have passed the single membrane filter, get settled. After this process, the mixture is allowed to pass through double net membrane filter and collected in Boiler Storage tank where the harvested rain water is mixed with regimented mixture of water.

Afterwards, this mixture of water is pushed to electric boiler powered with the solar PV Module which is installed with pressure regulating, heating and metering station in order to regulate the smooth flow of steam, and then this steam is allowed to naturally condense in order to form pure distilled water which is then pumped to a storage tank on the top of home / apartment / society / colony with the help of Solar PV Module.

The collected water is mechanically filtered and stored in underground tank having a capacity of 2000 Litres or above. The tank has a dual drainage pipe, one which has an upward opening to natural atmosphere in order to regulate the pressure in tank and the other one with a downward opening, if 
in case the water stored exceeds the permissible limits of storage tank.

Post this process, over a period of 60-85 days, a combination of methane and carbon dioxide will be formed within the district regulating system (Double Stream) due to aerobic and anaerobic reactions, which is commonly known as bio gas. This methane can be used instead of LPG for cooking and household purposes whereas carbon dioxide produced can be stored as a protective blanket for fire prevention.

Chlorination of the tank will be done on regular basis and storage Tank and single/double membrane filters are to be cleaned on regular intervals, in order to prevent bacterial growth in recycled water collection tank. This approach is environmental friendly and also solves the global Duck Curve Problem, as this process can be carried out during night hours when there is minimal requirement of energy hence improving the efficiency of process.

\subsection{Proposed System Components}

The preferred embodiment of this project, Green Flushing: Grey \& Black water Recycling, Recycling Rainwater solar powered toiletry flush mechanism with inbuilt biogas and fertilizer production system comprises of district regulating system (Double Stream), single membrane filter ( two in quantity ), double net membrane filter, pressure regulating, heating and metering station , electric boiler ( $200 \mathrm{~kg} / \mathrm{Hr}$ ), electrical pump ( 1.5 HP ) \& two storage tanks ( 1000 Litres each ).

\subsection{Proposed Mechanism Flowchart (Figure- 1)}

\section{RESULT}

Based on average calculations, an Indian household usually comprising of 5-6 members will require 30 flushes (subjected to condition that an individual might require 5 flushes per day). Each flush consumes approximately 10 litres of water which bring this calculation to about 300 litres per day. Also the electric consumption of a 740 watt pump is nearly about 22 units of electricity per month. If we generalise this given number in a colony of 20 families, we get a round figure of 6000 litres of water per day and 440 units of electricity a month. A table 
below depicts the results of water \& energy consumption for an average Indian Household colony v/s a projected green flushing household as depicted in this proposed research project.

Table 1: Normal Indian Household Colony Water and Energy Consumption v/s Green Economical Flushing for an average daily use. (Ref Table- 1)

- *Results are done on average calculations and 740 Watt Pump Motor is used as an example only.

- *This Data is as per BSES Website.

\section{CONCLUSION}

As per the sample utilisation data, the eco-friendly alternative proposes to reduce water and electrical consumption in magnanimous quantities thereby creating more efficient household and commercial disposal systems. The amalgamation of three resource-saving technologies incorporated at the cost of one product, a green flushing system provides an inexpensive alternative to saving the planet and preventing diseases. The long term effects of utilising the proposed mechanism provides the added benefit of cost effective sanitation especially for developing countries where the biofuel produced as a by-product will provide less hazardous conditions for cooking and more importantly, a fuel that is accessible to all.

\section{REFERENCES}

[1] Earth in future, Distribution of water on earth's surface: Drs. Timothy Bralower and David Bice, Professors of Geosciences, College of Earth and Mineral Science, The Pennsylvania State University. Retrieved from: https://www.e-

education.psu.edu/earth103/node/701

[2] United Nations Educational, Scientific and Cultural Organisation, World water Assessment Programme (WWAP), Retrieved from: http://www.unesco.org/new/en/naturalsciences/environment/water/wwap/fact s-and-figures/all-facts-wwdr3/fact-15water-pollution/

[3] Patent Publication No. 201128939

[4] Patent Publication No. 2001303649

[5] Patent Publication No. 2876202

[6] Patent Publication No. 20020066310

[7] US Patent No. 7,118,677 


\section{LIST OF FIGURES}

Figure- 1 Proposed Mechanism Flowchart

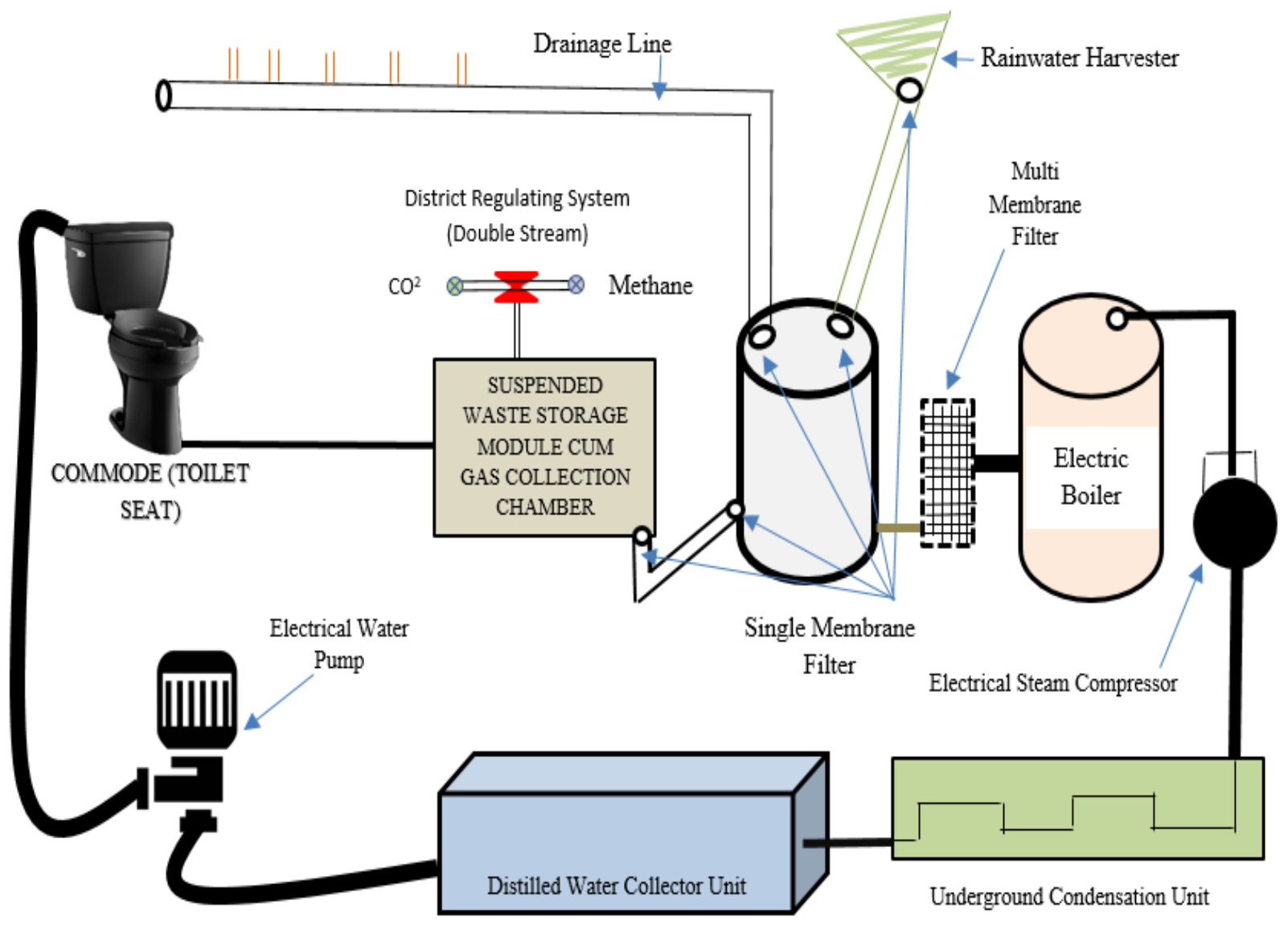

\section{LIST OF TABLE:}

Table- 1 Normal Indian Household Colony Water and Energy Consumption v/s Green Economical Flushing for an average daily use

\begin{tabular}{|c|c|c|}
\hline $\begin{array}{ll}\text { Household } & \text { Colony } \\
\text { Consumption } & \end{array}$ & Potable Water Consumed & $\begin{array}{l}\text { Electric } \\
\text { Consumed }\end{array}$ \\
\hline - $\quad$ Normal Toilet & - 6000 Litres / Day & - 440 Units/Month \\
\hline $\begin{array}{l}\text { - Green Economical } \\
\text { Toilet }\end{array}$ & $\begin{array}{l}\text { - Zero Litres / day ( } \\
\text { Since all the water } \\
\text { which is used is }\end{array}$ & $\begin{array}{l}\text { - Zero Units/ Month ( } \\
\text { Since all the water for } \\
\text { pumping and }\end{array}$ \\
\hline
\end{tabular}


ELK ASIA PACIFIC JOURNAL OF MECHANICAL ENGINEERING RESEARCH

ISSN 2349-9368 (Online); EAPJMER/issn. 2349-9368/2016; Volume 4 Issue 2 (2018)

\begin{tabular}{|l|l|l|}
\hline & $\begin{array}{l}\text { mechanically } \\
\text { recycled ) }\end{array}$ & $\begin{array}{l}\text { processing is done } \\
\text { with the help of solar } \\
\text { PV Module Battery } \\
\text { Unit ) }\end{array}$ \\
\hline
\end{tabular}

